\section{A survey on the hygienic standard of feeds for horses associated with diseases}

Petra Wolf, Manfred Coenen and Josef Kamphues

Institute of Animal Nutrition, University of Veterinary Medicine Hannover, Foundation

\section{Introduction}

A well balanced nutrition belongs to an essential condition for wellbeing or fitness as well as fertility or longevity of horses. Therefore, energy and nutrient supply is on interest, that can be assessed by feed intake (amounts, composition of feed) as well as by analyses of different parameters in body own substrates (blood, urine a.s.o.). Moreover, feeding technique has to be considered (relation of roughage to concentrate, frequency, amount per meal). However, tolerability of feeds, rations or techniques depends not least on hygienic quality of the offered feeds. In the following comments common lacks concerning hygienic status as well as consequences for horses' health will be presented. Following interpretation bases on 766 feedstuffs sent in to our institute in the years 2000 until end of june 2005. Therefore, it has to be commented critically, that these results do not reflect the actual situation in practice, because the evaluated feedstuffs were sent in due to health problems.

Faults in the hygienic standard of feedstuffs for horse Reason for analyses of the hygienic standard of the feeds

All feedstuffs were sent in with detailed preliminary reports. Colics or a reduced performance (tirednes, insufficient locomotion) belong to the common health problems. Moreover increased levels of liver enzymes, cough or allergic symptoms (oedema, "swollen legs") gave reason for analyses of feeds (fig. 1).

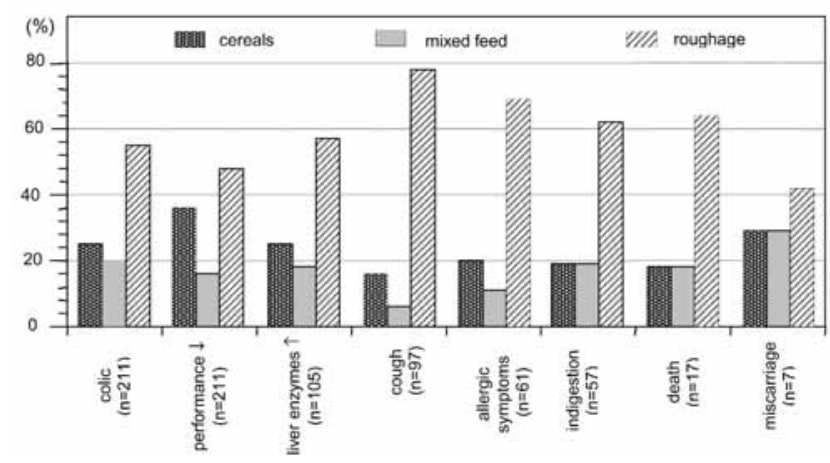

Fig 1 Common reasons for analyses of the hygienic standard of feeds.

\section{Sensory control}

A carefull sensory control (s.c.) gives first important information about the hygienic standard of the feedstuffs (see table 1).

Table 1 Feedstuffs for horses with hygienic faults in the sensory control.

\begin{tabular}{|c|c|c|c|c|c|c|c|c|c|c|}
\hline \multirow{2}{*}{\multicolumn{2}{|c|}{$\begin{array}{l}\text { feedstuff } \\
n=766\end{array}$}} & \multirow{3}{*}{$\begin{array}{c}\mathrm{n} \\
181\end{array}$} & \multicolumn{2}{|c|}{ smell } & \multicolumn{2}{|c|}{ appearance } & \multicolumn{2}{|c|}{ texture } & \multicolumn{2}{|c|}{ parasites ${ }^{* * *}$} \\
\hline & & & $\mathrm{n}$ & $\%$ & $n$ & $\%$ & $\mathrm{n}$ & $\%$ & $n$ & $\%$ \\
\hline \multirow{3}{*}{ I } & oats & & 55 & 30 & 132 & 73 & 14 & 8 & 28 & 15 \\
\hline & barley & 12 & 2 & 17 & 8 & 67 & 0 & $\cdots$ & 0 & $\cdots$ \\
\hline & corn & 5 & 1 & 20 & 0 & --- & 1 & 20 & 1 & 20 \\
\hline \multirow{3}{*}{ ॥ } & muesli & 62 & 13 & 27 & 7 & 11 & 7 & 17 & 7 & 17 \\
\hline & concentrate* & 57 & 0 & $\cdots$ & 2 & 4 & 1 & 2 & 5 & 9 \\
\hline & mash & 5 & 0 & -- & 0 & --- & 2 & 40 & 0 & $\cdots$ \\
\hline \multirow{3}{*}{ III } & hay & 247 & 87 & 35 & 104 & 42 & 73 & 30 & 93 & 38 \\
\hline & grass silage & 78 & 36 & 46 & 30 & 39 & 0 & --. & 2 & 3 \\
\hline & straw & 119 & 66 & 55 & 96 & 81 & 16 & 13 & 10 & 8 \\
\hline 1: & cereals & 198 & 58 & 29 & 140 & 71 & 15 & 7 & 29 & 15 \\
\hline II: & mixed feed** & 124 & 13 & 10 & 9 & 7 & 10 & 8 & 12 & 10 \\
\hline & roughage & 444 & 189 & 43 & 230 & 52 & 89 & 20 & 105 & 24 \\
\hline
\end{tabular}

For example, a heavy dusty character or a mouldy odour of the feedstuff correlated in many cases with a high level of moulds, a yeasty smell indicated high contents of yeasts. Moreover, a massive load by pests or mites was combined with a lower dry matter content of the feed that is related in general to higher counts of microorganisms. In the sensory control the parameter "texture" can be used to assess the dryness ( $\mathbb{E}$ shelf life) of the feeds (see figure 2).

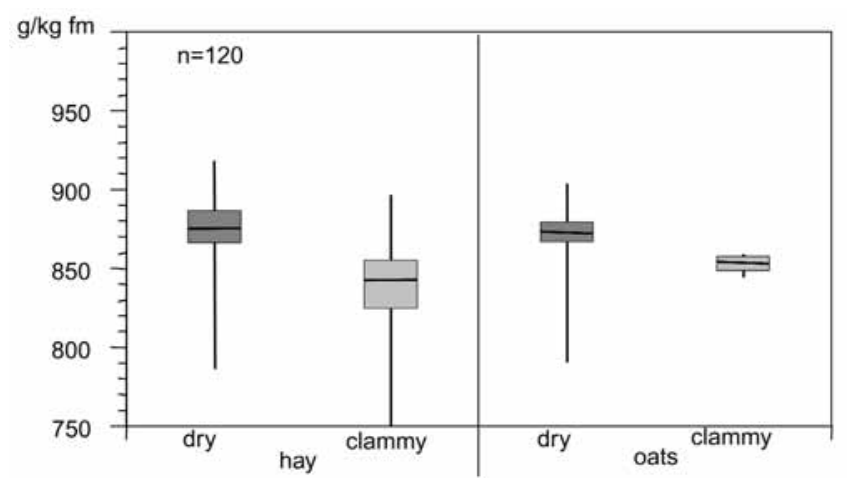

Fig 2 Expressivenes of the parameter "texture" (dry matter content of feed-stuffs characterized in the sensory control as "dry" or as "clammy").

\section{Microbiological status}

Usual microbiological analyses are informative for different feed stuffs (see table 2), but the interpretation of the results needs a distinction between epiphytes and germs that indicate spoilage (see contribution Kamphues) as well as between normal counts (n.c.) in different feeds.

Hygienic deviations in the hygienic quality could be observed in cereals and roughage, whereas commercial mixed feeds showed less imperfections.

\section{Lipopolysaccharides}

The classical microbiological investigation (cultural proof) of feedstuffs, that are submitted to different procedures at the processing (drying, high temperatures, intensive grinding, 
Table 2 Microbiological status of different feedstuffs for horses.

\begin{tabular}{|c|c|c|c|c|c|c|c|c|c|c|}
\hline & \multirow{2}{*}{$\begin{array}{c}\text { tota } \\
\text { I } \\
\text { n }\end{array}$} & \multicolumn{2}{|c|}{$\begin{array}{l}\text { aerobe germs } \\
\text { (cfu > n.c.) }\end{array}$} & \multirow{2}{*}{$\begin{array}{c}\text { total } \\
n\end{array}$} & \multicolumn{2}{|c|}{$\begin{array}{c}\text { moulds } \\
\text { (cfu }>\text { n.c.) }\end{array}$} & \multirow{2}{*}{$\begin{array}{c}\text { total } \\
n\end{array}$} & \multicolumn{2}{|c|}{$\begin{array}{c}\text { yeasts } \\
\text { (cfu }>\text { n.c.) }\end{array}$} \\
\hline & & & $n$ & $\%$ & & $n$ & $\%$ & & $n$ & $\%$ \\
\hline \multirow{3}{*}{ I } & oats & 156 & 58 & 37 & 158 & 51 & 32 & 153 & 54 & 35 \\
\hline & barley & 10 & 2 & 20 & 10 & 2 & 20 & 8 & 1 & 13 \\
\hline & corn & 5 & 2 & 40 & 5 & 1 & 20 & 5 & 1 & 20 \\
\hline \multirow{3}{*}{ II } & muesli & 53 & 18 & 34 & 54 & 7 & 13 & 46 & 6 & 13 \\
\hline & concentrate* & 42 & 3 & 7 & 46 & 3 & 7 & 42 & 1 & 2 \\
\hline & mash & 5 & 0 & -..- & 5 & 0 & $\ldots$ & 5 & 0 & -.- \\
\hline \multirow{3}{*}{ III } & hay & 218 & 52 & 24 & 232 & 80 & 34 & 206 & 15 & 7 \\
\hline & grass silage & 69 & 22 & 32 & 73 & 24 & 33 & 71 & 31 & 44 \\
\hline & straw & 100 & 50 & 50 & 111 & 46 & 41 & 108 & 16 & 15 \\
\hline 1 & cereals & 171 & 62 & 36 & 173 & 54 & 31 & 166 & 56 & 34 \\
\hline II & mixed feed** & 100 & 21 & 21 & 105 & 10 & 10 & 93 & 8 & 9 \\
\hline III & roughage & 387 & 124 & 32 & 416 & 150 & 36 & 385 & 62 & 16 \\
\hline
\end{tabular}

high pressure, addition of acids a.s.o.) gives sometimes no dependable results. In these cases the determination of the lipopolysaccharide level (= LPS; part of the cell wall of gramnegative germs) gives indirectly information about the hygienic standard of the feedstuffs (see table 3).

Table 3 Lipopolysaccharide levels of different feedstuffs for horses.

\begin{tabular}{|c|c|c|c|c|c|c|c|c|}
\hline & \multirow{3}{*}{$\begin{array}{c}\text { total } \\
\mathrm{n}\end{array}$} & \multicolumn{6}{|c|}{ lipopolysaccharide level $(\mu \mathrm{g} / \mathrm{g})$} \\
\hline & & & \multicolumn{2}{|c|}{$<20$} & \multicolumn{2}{|c|}{$20-50$} & \multicolumn{2}{|c|}{$>50$} \\
\hline & & & $\mathrm{n}$ & $\%$ & $\mathrm{n}$ & $\%$ & $\mathrm{n}$ & $\%$ \\
\hline \multirow{3}{*}{ I } & oats & 112 & 36 & 32 & 23 & 21 & 53 & 47 \\
\hline & barley & 9 & 4 & 44 & 3 & 33 & 2 & 22 \\
\hline & corn & 4 & 3 & 75 & 1 & 25 & 0 & $\cdots$ \\
\hline \multirow{3}{*}{ ॥ } & muesli & 41 & 32 & 78 & 5 & 12 & 4 & 10 \\
\hline & concentrate* & 28 & 20 & 71 & 8 & 29 & 0 & --- \\
\hline & mash & 5 & 3 & 60 & 2 & 40 & 0 & --- \\
\hline \multirow{3}{*}{ III } & hay & 123 & 30 & 24 & 26 & 21 & 67 & 55 \\
\hline & grass silage & 17 & 5 & 29 & 7 & 41 & 5 & 29 \\
\hline & straw & 45 & 3 & 7 & 9 & 20 & 33 & 73 \\
\hline I & cereals & 125 & 43 & 34 & 27 & 22 & 55 & 44 \\
\hline II & mixed feed** & 74 & 55 & 74 & 15 & 20 & 4 & 5 \\
\hline III & roughage & 185 & 38 & 21 & 42 & 23 & 105 & 57 \\
\hline
\end{tabular}

\section{Health problems related to a reduced hygienic standard}

Based on a critical sensoric examination as well as continued analyses these suspicions could be beared out in many cases (see table 4).

\section{Conclusion}

A critical proof of the feedstuffs from the delivery until feeding is a fundamental condition to avoid health disorders or reduced performance caused by lacks of the hygienic standard. Veterinarians should be able to assess the hygienic quality of the offered feedstuffs (in particular in cases with a high frequency of colics, disorders of the respiratory tract a.s.o.). However, not the industrially produced mixed feeds/concen-
Table 4 Health disorders of preliminary report and findings of feed analyses.

\begin{tabular}{|c|c|c|c|c|c|c|c|}
\hline \multirow[t]{2}{*}{ health disorders } & \multirow{2}{*}{$\begin{array}{c}\text { samples } \\
n\end{array}$} & \multirow{2}{*}{$\begin{array}{l}\text { lacks } \\
\text { n (\%) }\end{array}$} & \multicolumn{5}{|c|}{ in the criticized feedstuffs lacks concerning ... } \\
\hline & & & s.c. & LPS & bacteria & moulds & yeasts \\
\hline colics & 211 & $115(55)$ & $63(55)^{1}$ & $75(65)$ & $49(43)^{2}$ & $54(47)$ & $56(49)$ \\
\hline performance $\downarrow$ & 211 & $82(39)$ & $28(34)$ & $58(71)$ & $8(10)$ & $25(30)$ & $7(9)$ \\
\hline liver enzymes $\uparrow$ & 105 & $50(48)$ & $25(50)$ & $39(78)$ & $10(20)$ & $10(20)$ & $8(16)$ \\
\hline cough & 97 & $52(54)$ & $23(44)^{1}$ & $33(63)$ & $25(48)$ & $32(62)$ & $24(46)$ \\
\hline allergic symptoms & 61 & $23(38)$ & $12(52)$ & $14(67)$ & $7(30)$ & $12(52)$ & $6(26)$ \\
\hline indigestions & 57 & $22(39)$ & $7(32)$ & $18(82)$ & $2(9)$ & $7(32)$ & $11(50)$ \\
\hline
\end{tabular}

trates, but especially the roughage (even if it is only used as bedding material like straw) are worthy of note and should be proofed critically (intensive sensory control combined with further analyses).

\section{References}

Coenen M. and Kienzle E. (1992): Beobachtungen zur hygienischen Beschaffenheit von Futtermitteln für Pferde in der tierärztlichen Ernährungsberatung. Sonderheft Pferdeheilkunde 8, 209-212

Kamphues J. (1986): Lipopolysaccharide in Futtermitteln - mögliche Bedeutung, Bestimmung und Gehalte. Übers Tierernährg $14,131-156$

Kamphues J. (1993): Futter und Fütterung - Beziehungen zur Gesundheit des Atmungstraktes. Mh Vet Med 48, 45-47

Kamphues J. (1996): Risiken durch Mängel in der hygienischen Beschaffenheit von Futtermitteln für Pferde. Pferdeheilkunde 12, 326-332

Kamphues J., Fimmen H., Küstermann S. and Meyer H. (1991): Lipopolysaccharides in feedstuffs for horses. Equine Vet Sci 11, 36-41

Kamphues J., Coenen M., Kienzle E., Pallauf J., Simon O. and Zentek J. (2004): Supplemente zu Vorlesungen und Übungen in der Tierernährung, 10. Aufl., Alfeld: Schaper

Küstermann S. (1989): Eine Feldstudie zum Hygienestatus von Pferdefuttermitteln unter besonderer Berücksichtigung des Lipopolysaccharidgehaltes. Med. Vet. Diss. Hannover

Meyer H., Heckötter E., Merkt M., Bernoth E., Kienzle E. and Kamphues J. (1986): Aktuelle Ergebnisse aus der tierärztlichen Fütterungsberatung. 6. Mittlg. Schäden durch Futtermittel beim Pferd. Dtsch Tierärztl Wschr 93, 486-490

Meyer H. and Coenen M. (2002): Pferdefütterung. 4. Aufl., Berlin: Parey

P. Wolf

Institute of Animal Nutrition

University of Veterinary Medicine Hannover, Foundation

Bischofsholer Damm 15

D-30173 Hannover

Petra.Wolf@tiho-hannover.de 